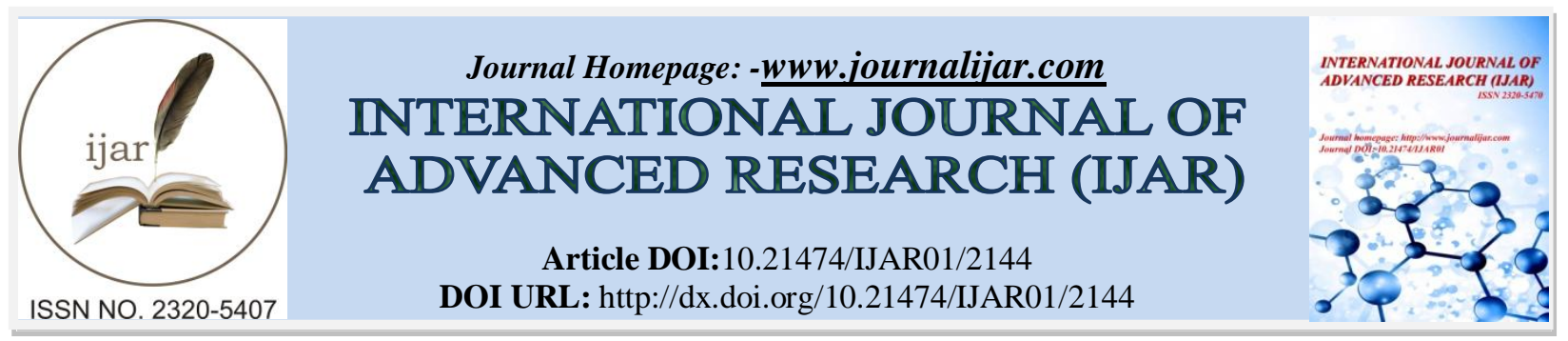

RESEARCH ARTICLE

\title{
EXAMINING RELATIONSHIP BETWEEN NIFTY 50 AND SELECTED SHARES IN NSE.
}

\section{Dr. U. Raghavendra Prasad.}

Assistant Professor Department of Management Studies Madanapalle Institute of Technology \& Science (UGCAutonomous) Madanapalle-517325.

\section{Manuscript Info}

Manuscript History

Received: 25 September 2016

Final Accepted: 27 October 2016

Published: November 2016

Key words:-

Index, Market capitalization, Nifty, NSE,

Stock Market.

\section{Abstract}

A stock market index is created by selecting a group of stocks that are representative of the whole market or a specified sector or segment of the market. Stock market indexes are meant to capture the overall behaviour of equity markets. The Nifty 50 is a well diversified 50 stock index. It is used for a variety of purposes such as benchmarking fund portfolios, index based derivatives and index funds. The objective of this paper is to examine the Nifty 50 associated with selected securities in NSE. The author has taken the data from 02-Jan2012 to 09-Sep-2016 (1164 observations) and studied the correlation coefficient to establish relationship between the Nifty 50 and selected shares in NSE.

Copy Right, IJAR, 2016,. All rights reserved.

\section{Introduction:-}

The National Stock Exchange (NSE) is India's leading stock exchange covering various cities and towns across the country. NSE was set up by leading institutions to provide a modern, fully automated screen-based trading system with national reach. The Exchange has brought about unparalleled transparency, speed \& efficiency, safety and market integrity. It has set up facilities that serve as a model for the securities industry in terms of systems, practices and procedures.

NSE has played a catalytic role in reforming the Indian securities market in terms of microstructure, market practices and trading volumes. The market today uses state-of-art information technology to provide an efficient and transparent trading, clearing and settlement mechanism, and has witnessed several innovations in products \& services viz. demutualisation of stock exchange governance, screen based trading, compression of settlement cycles, dematerialisation and electronic transfer of securities, securities lending and borrowing, professionalisation of trading members, fine-tuned risk management systems, emergence of clearing corporations to assume counterparty risks, market of debt and derivative instruments and intensive use of information technology. A stock market index is a measure of the relative value of a group of stocks in numerical terms. As the stocks within an index change value, the index value changes. An index is important to measure the performance of investments against a relevant market index.The Nifty 50 is a well diversified 50 stock index accounting for 13 sectors of the economy. It is used for a variety of purposes such as benchmarking fund portfolios, index based derivatives and index funds.

Nifty 50 is owned and managed by India Index Services and Products Ltd. (IISL). IISL is India's first specialised company focused upon the index as a core product.The Nifty 50 Index represents about $65 \%$ of the free float market capitalization of the stocks listed on NSE as on March 31, 2016.

Corresponding Author: -Dr. U. Raghavendra Prasad.

Address: -Assistant Professor Department of Management Studies Madanapalle Institute of Technology \& Science (UGC-Autonomous) Madanapalle-517325. 
The total traded value of Nifty 50 index constituents for the last six months ending March 2016 is approximately $46 \%$ of the traded value of all stocks on the NSE.Impact cost of the Nifty 50 for a portfolio size of Rs.50 lakhs is $0.04 \%$ for the month March 2016.Nifty 50 is professionally maintained and is ideal for derivatives trading.From June 26, 2009, Nifty 50 is computed based on free float methodology.

\section{Review of literature:-}

Babu, M., \&Hariharan, C. (2014). Investigated the volatility in the Indian stock market. There are twelve sectoral indices in NSE of which five indices, namely, CNX AUTO, CNX BANK, CNX FINANCE, CNX IT, and CNX PHARMA were selected for analysing the volatility of sectoral indices. The criterion for selecting the sample indices was the turn over during the study period from January 2009 to December 2013.

Rajamohan, S., \&Muthukamu, M. (2014). An attempt is made in this study to know the nature Pearson correlation coefficient technique is applied to find the nature and extent of influence by banking sector with other sectors and it was found that there is a positive correlation between banking stock index and most of the other sectoral stock indices.

Dr.G.Shanmugasundram and D.John Benedict (2013) made an attempt to provide an empirical support to identify the risk factors in sectoral indices and CNX Nifty index and also to see the risk relationship in different time intervals. The indices selected for the study are CNX Nifty index, CNX Auto index, CNX Bank index, CNX FMCG index, CNX Infrastructure index and CNX Information Technology index for the period from 01/01/2004 to 30/04/2012. Two sample T-Test and One - way ANOVA between subjects has been used to identify the risk factor difference across the risk of sectoral indices and CNX Nifty index.

Chittedi, K. R. (2011). Examined the stock indices of the developed countries with relation to India for a period of 10 years (1 October 1997-1 October, 2007) out the integration between them. For this purpose, Unit Roots, Granger Causality, co-integration and Error correction Mechanism are used. To examine the short-run and long-run relationships between India and the developing counties. The study found that co integration existing between India and developed countries. (USA, UK, Japan, France and Australia).

Siddiqui, S. (2008). Studied that due to globalization, economic integration among countries and their financial markets is evident. The interdependency between Indian and other European stock markets has also increased. This paper examines the relationships between selected European stock markets and SENSEX. It covers closing data of nine stock markets to investigate.

\section{Objectives of the study:-}

The objective of the study is to find out the nature and extent of relationship between Nifty 50 and selected shares in NSE (from 02-Jan-2012 to 09-Sep-2016) (1164 observations).

\section{Methodology:-}

The data required for the study is collected from secondary source. Secondary data for thepresent study has been collected from NSE and money control websites. The selected shares for this study are top four market capitalization companies in NSE in India as on 09-09-2016. The closing prices of the Nifty 50 and selected shares from 02-Jan2012 to 09-Sep-2016(1164 observations) have been collected from NSE.Data was analysed through Karl Pearson's Correlation Coefficient Method.

Table: 1 Top four market capitalization companies in NSE (as on 09-09-2016)

\begin{tabular}{|c|c|}
\hline Company Name & Market Cap(Rs. cr) \\
\hline TCS & $463,533.32$ \\
\hline Reliance & $338,742.50$ \\
\hline HDFC Bank & $327,561.65$ \\
\hline ITC & $312,533.12$ \\
\hline
\end{tabular}

Source: www.moneycontrol.com 


\section{Hypothesis of the study:-}

$\mathrm{H}_{0}$ : There is no significant relationship between Nifty 50 and selected shares.

Ha: There is a significant relationship between Nifty 50 and selected shares.

\section{Data analysis:-}

A Pearson product-moment correlation was run to determine the relationship between Nifty 50 and HDFC Bank. There was a very high positive correlation of 0.936between Nifty 50 and HDFC Bank and which was statistically significant $(r=.936, n=1164, p=.000$ ). Whereas for Nifty 50 and TCS there was a very high positive correlation of 0.922 and which was also statistically $\operatorname{significant}(r=.922, n=1164, p=.000)$.

Table: 2 Correlations

\begin{tabular}{|c|c|c|c|c|c|c|}
\hline & & NIFTY 50 & TCS & Reliance & HDFC Bank & ITC \\
\hline \multirow[t]{3}{*}{ NIFTY 50} & $\begin{array}{l}\text { Pearson } \\
\text { Correlation }\end{array}$ & 1 & $.922^{* * *}$ & $.755^{* *}$ & $.936^{* *}$ & $.576^{* *}$ \\
\hline & Sig. (2-tailed) & & .000 & .000 & .000 & .000 \\
\hline & $\mathrm{N}$ & 1164 & 1164 & 1164 & 1164 & 1164 \\
\hline \multirow[t]{3}{*}{ TCS } & $\begin{array}{l}\text { Pearson } \\
\text { Correlation }\end{array}$ & $.922^{* * *}$ & 1 & $.749^{* *}$ & $.850^{* *}$ & $.667^{* * *}$ \\
\hline & Sig. (2-tailed) & .000 & & .000 & .000 & .000 \\
\hline & $\mathrm{N}$ & 1164 & 1164 & 1164 & 1164 & 1164 \\
\hline \multirow[t]{3}{*}{ Reliance } & $\begin{array}{l}\text { Pearson } \\
\text { Correlation }\end{array}$ & $.755^{* *}$ & $.749^{\text {** }}$ & 1 & $.727^{* *}$ & $.505^{* *}$ \\
\hline & Sig. (2-tailed) & .000 & .000 & & .000 & .000 \\
\hline & $\mathrm{N}$ & 1164 & 1164 & 1164 & 1164 & 1164 \\
\hline \multirow[t]{3}{*}{$\begin{array}{l}\text { HDFC } \\
\text { Bank }\end{array}$} & $\begin{array}{l}\text { Pearson } \\
\text { Correlation }\end{array}$ & $.936^{* *}$ & $.850^{2 * *}$ & $.727^{* *}$ & 1 & $.444^{* * *}$ \\
\hline & Sig. (2-tailed) & .000 & .000 & .000 & & .000 \\
\hline & $\mathrm{N}$ & 1164 & 1164 & 1164 & 1164 & 1164 \\
\hline \multirow[t]{3}{*}{ ITC } & $\begin{array}{l}\text { Pearson } \\
\text { Correlation }\end{array}$ & $.576^{* *}$ & $.667^{* * 2}$ & $.505^{* *}$ & $.444^{* * *}$ & 1 \\
\hline & Sig. (2-tailed) & .000 & .000 & .000 & .000 & \\
\hline & $\mathrm{N}$ & 1164 & 1164 & 1164 & 1164 & 1164 \\
\hline \multirow[t]{3}{*}{ Infosys } & $\begin{array}{l}\text { Pearson } \\
\text { Correlation }\end{array}$ & $-.418^{* * *}$ & $-.267^{* *}$ & $-.245^{* * *}$ & $-.661^{\text {*** }}$ & $.094^{* * *}$ \\
\hline & Sig. (2-tailed) & .000 & .000 & .000 & .000 & .001 \\
\hline & $\mathrm{N}$ & 1164 & 1164 & 1164 & 1164 & 1164 \\
\hline
\end{tabular}

Source: Secondary data

With respect to Nifty 50 and Reliancethere was a strong, positive correlation and which was statistically significant $(r=.755, n=1164, p=.000)$. Similarly for Nifty 50 and ITCthere was a moderate, positive correlation and which was statistically significant $(r=.576, n=1164, p=.000)$.

\section{Conclusion:-}

A stock market index is created by selecting a group of stocks that are representative of the whole market or a specified sector or segment of the market. Stock market indexes are meant to capture the overall behaviour of equity markets. The Nifty 50 is a well diversified 50 stock index. It is used for a variety of purposes such as benchmarking fund portfolios, index based derivatives and index funds. There is a strong positive correlation between Nifty 50 and HDFC Bank, TCS, Reliancewhereas for Nifty 50 and ITC it is a moderate positive correlation. 


\section{References:-}

1. Ahmad, K. M., Ashraf, S., \& Ahmed, S. (2005). Is the Indian stock market integrated with the US and Japanese markets? An empirical analysis. South Asia Economic Journal, 6(2), 193-206.

2. Ameer, R. (2006). Integration of the South and East Asian stock markets: how long to go? Journal of Financial Reporting and Accounting, 4(1), 61-102.

3. Babu, M., \&Hariharan, C. (2014). Efficiency of Indian Sectoral Indices: An Empirical Study with Special Reference with National Stock Exchange India Ltd. Asia-Pacific Finance and Accounting Review, 2(1/2), 87.

4. Bose, S., \& Mukherjee, P. (2006, February). A Study of Inter linkages Between the Indian Stock Market and Some Other Emerging and Developed Markets. In Indian Institute of Capital Markets 9th Capital Markets Conference Paper.

5. Brailsford, T. J., Penm, J. H., \& Terrell, R. D. (2006). An analysis of Asian market integration pre-and postcrisis. International Journal of Theoretical and Applied Finance, 9(04), 483-501.

6. Chittedi, K. R. (2011). Integration of International Stock Markets: With Special Reference to India. Gandhi Institute of Technology and Management (GITAM), Journal of Management, 9(3).

7. Deepak, R., \& Sandeep, M. (2013). Integration of Indian markets with select global markets: changing paradigms and dynamics. International Journal of Innovative Research and Development|| ISSN 2278$0211,2(12)$.

8. Dr.G.Shanmugasundram and D.John Benedict(2013) in their article "Volatility Of The Indian Sectoral Indices A Study With Reference To National Stock Exchange", International Journal of Marketing, Financial Services \& Management Research,ISSN 2777- 3622,Vol.2,No.8.

9. Joshi, P. (2011). Market integration and efficiency of Indian stock markets: A study of NSE. NSE Paper, (198), $1-29$.

10. Marimuthu, M. (2010). The co-movements of the regional stock markets and some implications on risk diversification. IUP Journal of Applied Economics, 9(2), 61.

11. Mehta, K., \& Sharma, R. (2013). Association in Emerging Asian Stock Markets: A Test of Co-Integration. In International Conference on Management and Information Systems September (Vol. 22, p. 24).

12. Mukherjee, D., Nath, K., \& Mishra, R. K. (2006). International stock market integration and its economic determinants: A study of Indian and world equity markets. RK, International Stock Market Integration and Its Economic Determinants: A Study of Indian and World Equity Markets (March 2006).

13. Mukherjee, P., \& Bose, S. (2008). Does the stock market in India move with Asia? A multivariate cointegration-vector auto regression approach.Emerging Markets Finance and Trade, 44(5), 5-22.

14. Patel, S. A. (2013). Dynamic Linkages of Developed Equity Markets with Indian Stock Market. Vilakshan: The XIMB Journal of Management, 10(1).

15. Rajamohan, S., \&Muthukamu, M. (2014, April). Bank Nifty Index and Other Sectoral Indices of NSE- A Comparative Study. PARIPEX - Indian Journal of Research, 3(4).

16. Siddiqui, S. (2008). Exploring integration between selected European stock market indexes and Sensex. Pranjana, 11(2), 79-90.

17. Singh, R. P., \& Gandhi, M. (2015). A Study of Causality and Co-Integration Effect among the BRICS Countries Stock Exchanges-A Relationship Study.Singh, RP, \& Gandhi, M. (2014). A Study of Causality and CoIntegration effect among the BRICS Countries Stock Exchanges-A relationship study. Business Rethinking in 21 st Century, 435-447.

18. Srikanth, P. (2012). Integration of Indian stock market with other markets in the Asia-Pacific region. IUP Journal of Financial Economics, 10(1), 18.

19. Taneja, Y. P. (2012). Stock Market Integration: A Study of World's Major Stock Exchanges with Special Reference to India. Vision: The Journal of Business Perspective, 16(2), 109-120.

20. www.nseindia.com

21. www.moneycontrol.com 